"Mircea cel Batran" Naval Academy Scientific Bulletin, Volume XIX - 2016 - Issue 2

\title{
LANDSCAPES OF SETTLEMENTS IMPOSED BY ELEMENTS BASINS IN THE SUBCARPATHIC AREA BETWEEN BUZAU AND RAMNIC
}

\author{
Constantin MORARU ${ }^{1}$ \\ Marin ION ${ }^{2}$ \\ ${ }^{1}$ Technological High School, Starchiojd Town \\ ${ }^{2}$ University Bucharest, Romania
}

\begin{abstract}
The Subcarpathic of Buzau and Râmnic represents a territorial unit, closely linked to the codealtitude aerial drops is a major factor in the definition of the landscape,but especially in the amendment or to conservation. It prints a dynamic permanent and that can introduce significant changes including in the countryside, in the landscape the settlements. Rivers, permanent or temporary, have transformed by erosion, transport and build a space relatively geographically homogeneously by his natural and socio-human in one qualitatively and quantitatively with other dimensions.
\end{abstract}

Keywords: flood, Buildings meant, water inrushes, debts,slopes, abdicated cured

\section{INTRODUCTION}

Landscapes imposed on the systems of the hydrographic basins the Subcarpathic area Buzau and Râmnic, taking into account the flow structure of the solid or liquid, will be expressed in terms of the main network place main fluviatile, on that molds and the other features of the detail of the environment including geographical and the settlements and then details, special notes introduced by local factors or regional ones. Due to the huge quantities of alluvial deposits in suspension carried by rivers that and phenomena erozionale prior to build, it has been found that the Subcarpathic area Buzau and Ramnic is one of the most degraded regions of the country and that improve this imbalance with natural broad anthropogenic contribution, is a complex process and long-lasting (Balteanu,D., 1971).

Even though the dimensions of the hydrographic basins are an average value however, zones of the confluence have been especially in the occurrence of a favorable climate for floods, the price increases the level and flow at certain times of the year, against the background of the large oscillation of these areas of authentic risk. It is the outflow of spring and torrential rain in the summer.

\section{MATERIALS AND METHODS}

In the sector of subcarpatic have been highlighted the following methods.

The first method used for quantification of the fragmentation of the landscape involves the calculation and analysis of the landscape metricilor (Apan et al., 2000).

The second method involves the identification and description of the relations between the dynamics of the landscape the subcarpathic and topographic aspects of the catchment area of the Slanic and Calnau.

The third method shall assess all the transformations occurring in the way the coverage or use of land within the period analyzed.

\section{RESULTS}

Let us not forget that the spring, the values of the average leakage represents about half of the annual leak (dealt with by Geography, 1992). To these are added the outflow of alluvial deposits which Calnau reaches $56 \mathrm{t} / \mathrm{ha} / \mathrm{year}$ and the Slanic at $43,0 \mathrm{t} / \mathrm{ha} /$ year. In this situation as well as the settlements Calnaului Mouth, Maracineni, Sapoca, Parscov, Berca, Ratesti a.s. have borne the floods accompanied by important material injury. The crossing of the rivers of and makes the cobweb of them to have broken waveforms, in which water tap the power, which lead to the destruction of the banks, of the roads and the houses from the shore ( Cojani, Braesti). The landscape the settlements situated in areas of the confluence is vulnerable and with many components that are changing that physiognomy, structure, etc. Rarely has been tampered with substantially to redefine the landscape,, however some measures for the prevention or improving ( fig.1). 
"Mircea cel Batran" Naval Academy Scientific Bulletin, Volume XIX - 2016 - Issue 2 The journal is indexed in: PROQUEST / DOAJ / Crossref / EBSCOhost / INDEX COPERNICUS / DRJI / OAJI / JOURNAL INDEX / I2OR / SCIENCE LIBRARY INDEX / Google Scholar / Academic Keys/ ROAD Open Access I Academic Resources / Scientific Indexing Services / SCIPIO / JIFACTOR

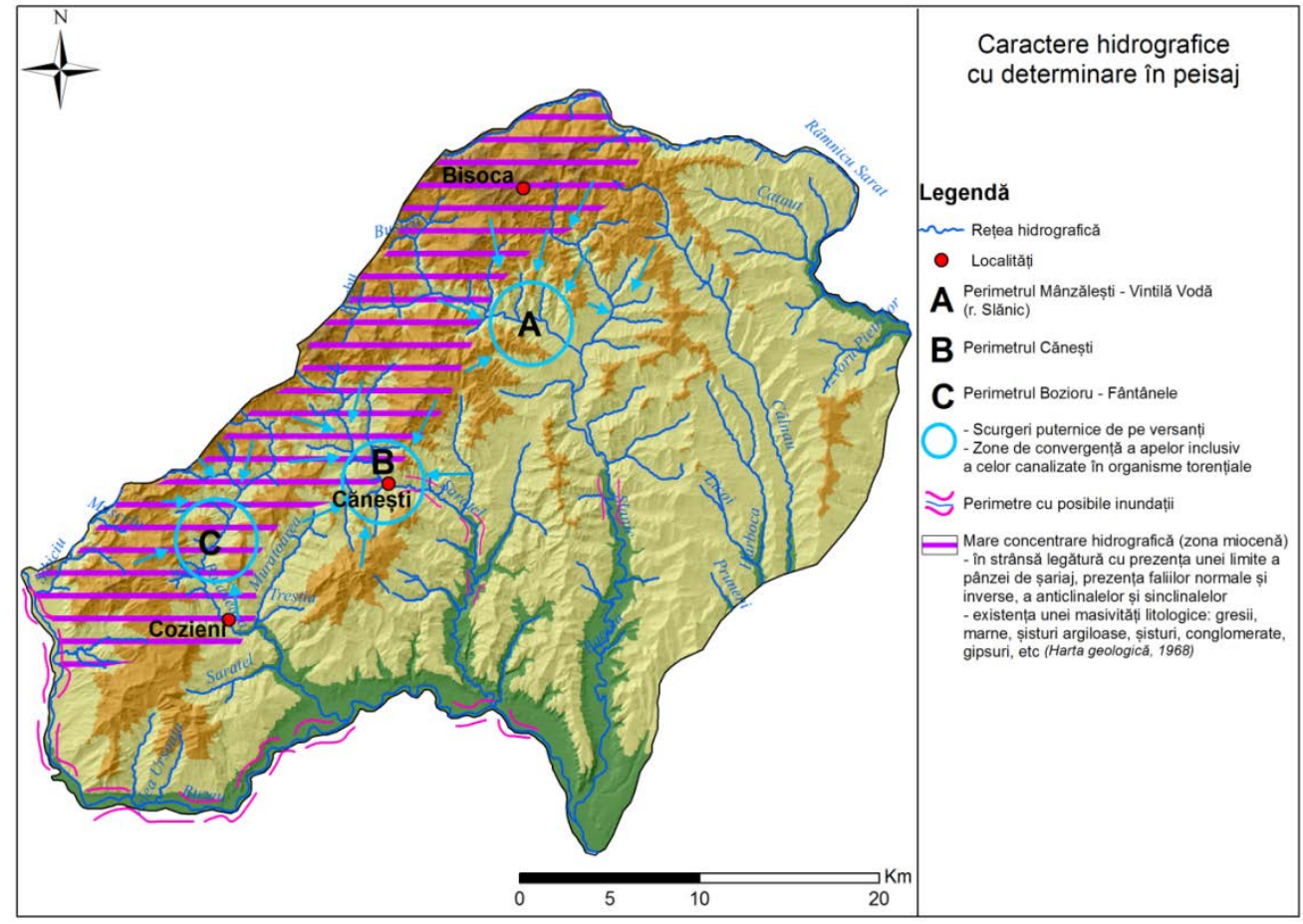

Figure 1. Characters hydrographic basins with determination in landscape (support topographic map)

The Subcarpathic area Buzau and Râmnic have a network of waters which by his morfometrice, chemical, physical, or certain specific manifestations times of the moment to impose on the elements of the landscape dynamics of the most interesting. The practical is "Engine" main energy which molds, print, makes and transforms, sometimes radical, components of the terrestrial environment as reflected highly visible on the intervals of spatio-temporal greater or smaller. Looked at from the angle of the relations between the potential use of water resources and the nature of the catastrophic events such as hydrological, rivers more attracted than was opposed by human activities. Very often, where geomorphological characteristics do not have a restrictive character, the villages are located in valleys, along the rivers, under which may benefit from a surplus of resources. In the framework of the hydrotechnical works for the construction of the rivers have been by gravity of certain sectors have been built fascinaje from lynneage, and thresholds of wood for the consolidation of versantilor slope ( Posea, G., 1971).

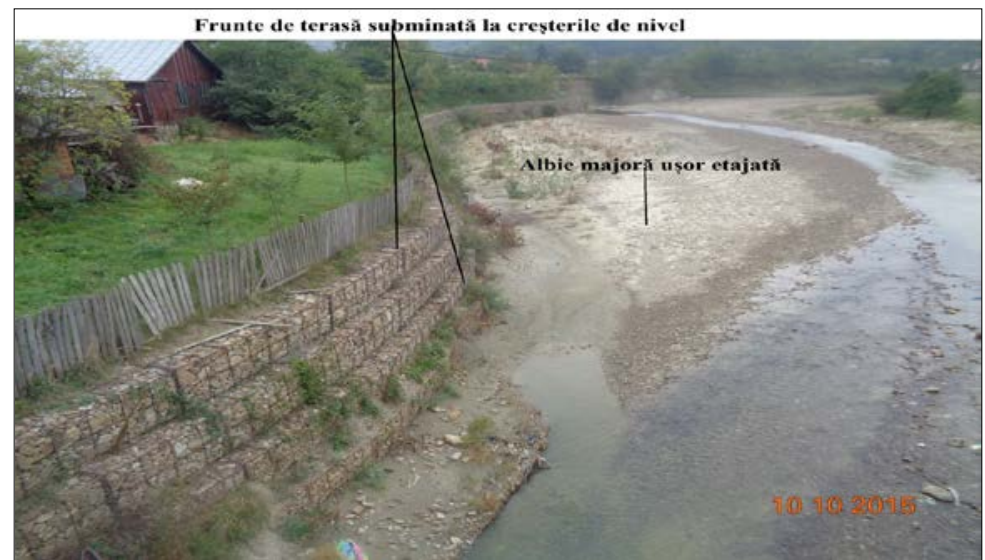

Figure. 2. The Slanic - hydrotechnical facilities (photo: Constantin Moraru, 2015) 
"Mircea cel Batran" Naval Academy Scientific Bulletin, Volume XIX - 2016 - Issue 2

The journal is indexed in: PROQUEST / DOAJ / Crossref / EBSCOhost / INDEX COPERNICUS / DRJI / OAJI I JOURNAL INDEX I I2OR / SCIENCE LIBRARY INDEX / Google Scholar / Academic Keys/ ROAD Open Access I Academic Resources / Scientific Indexing Services / SCIPIO / JIFACTOR

Dams are used to: water supply to the population, production of electricity, irrigation, a favorable climate for floods. These buildings meant were confirmed effective against the frequent floods or environments, the local and major events after raising their (fig. 2).
Branches of the river Buzau, in the area of hill and mountain (Panatau, Balaneasa, Saratel, Paclele), water content uncontrolled, there have been significant increases of levels and flows. In these same areas were strong leaks on the slopes and in the bodies with cadastral unregistered (fig. 3)

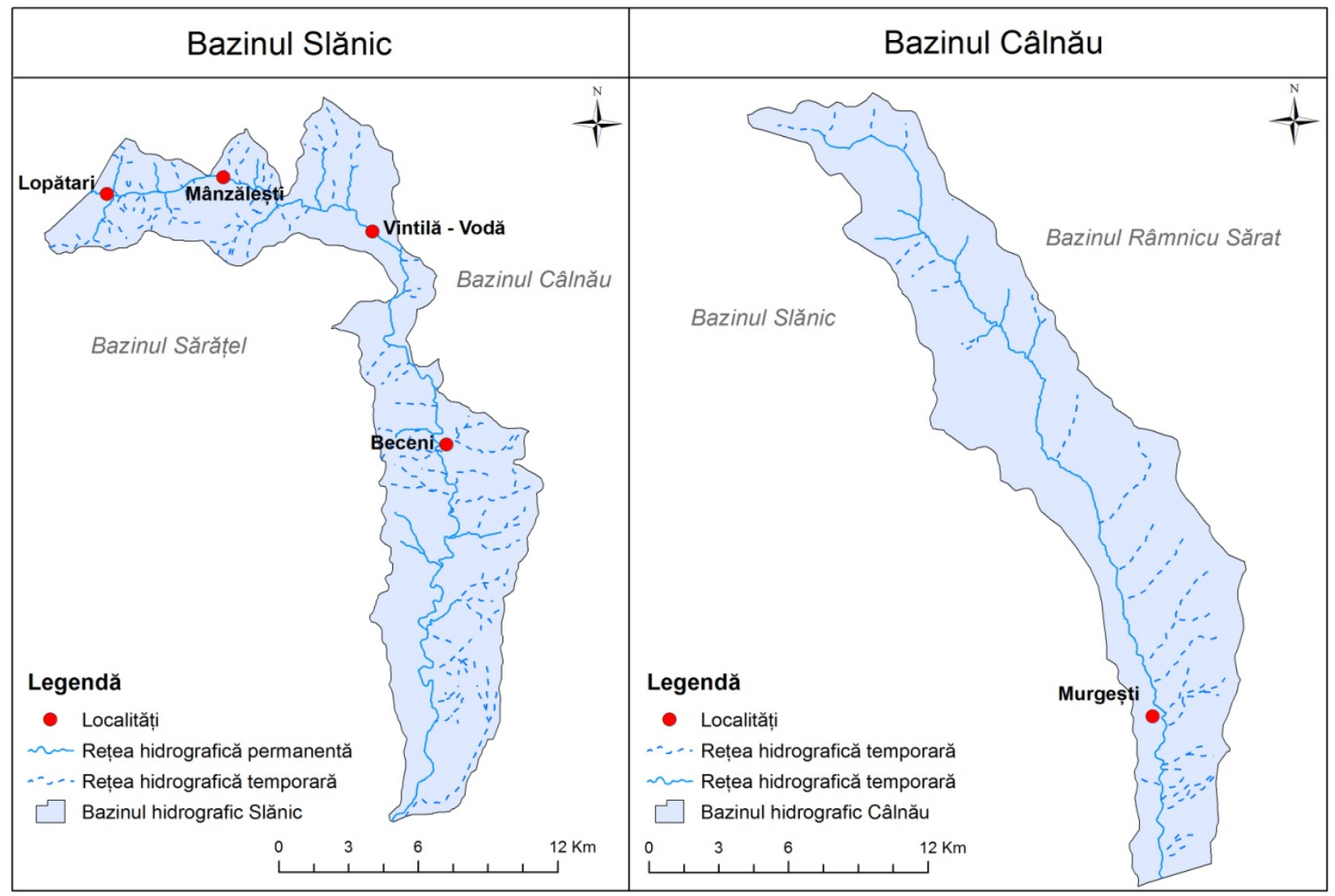

Figure 3. The coalfields Slanic and Calnau (support topographic map)

\section{CONCLUSIONS}

To mitigate the effects of floods in the basin of the river Buzau, were constructed works with the role of defense against calamities, in accordance with the traditional approach applied in Romania, also taking into account the fact that in the upper part of the pelvis focuses the maximum value of the quantitative precipitation and the intensity, leading to important flows downstream, respectively Siriu accumulations and Cândești .

Siriu lake is located on the Upper Valley of the river Buzau (Common Siriu). Register as an area of 2,6 km and a depth of $45 \mathrm{~m}$. The lake Cândești - lake located on the river Buzau, at $19 \mathrm{~km}$ upstream of the city of Buzau, in the area of the village Cândești $\left(0.6 \mathrm{~km}^{2}\right.$ surface and $5 \mathrm{~m}$ depth of the average). The volumes of water are kept of 155 million $\mathrm{m}^{3}$ and 3,7 million $\mathrm{m}^{3}$.

Following these phenomena have affected several localities such as Pătârlagele, Fangs, Parscov, Bozioru, Canesti, crusty, Tisau, Manzalesti, Beceni, Ulmeni and Năeni.

Due to increased flows upstream accumulation Cândeşti, where over the flow hydrometric station Magura added creeks flow increased Balaneasa, Sărăţel and Murătoarea (Pâclele).

For centuries, human communities settled primarily along the Buzau river, the river that provides power required permanent population and agricultural activities, but also generated many problems in terms of characteristic manifestations (fig.4). United Bâsca, and other tributaries (Basca Chiojdului, Balaneasa, Slănic 
"Mircea cel Batran" Naval Academy Scientific Bulletin, Volume XIX - 2016 - Issue 2 The journal is indexed in: PROQUEST / DOAJ / Crossref / EBSCOhost / INDEX COPERNICUS / DRJI / OAJI / JOURNAL INDEX / I2OR / SCIENCE LIBRARY INDEX / Google Scholar / Academic Keys/ ROAD Open Access I Academic Resources / Scientific Indexing Services / SCIPIO I JIFACTOR

Nişcov, Câlnău, Sărăţel) having a negligible contribution with value $1 \mathrm{m3} / \mathrm{s}$ - annual average (Gâştescu, P., Neagu, I. 1986).

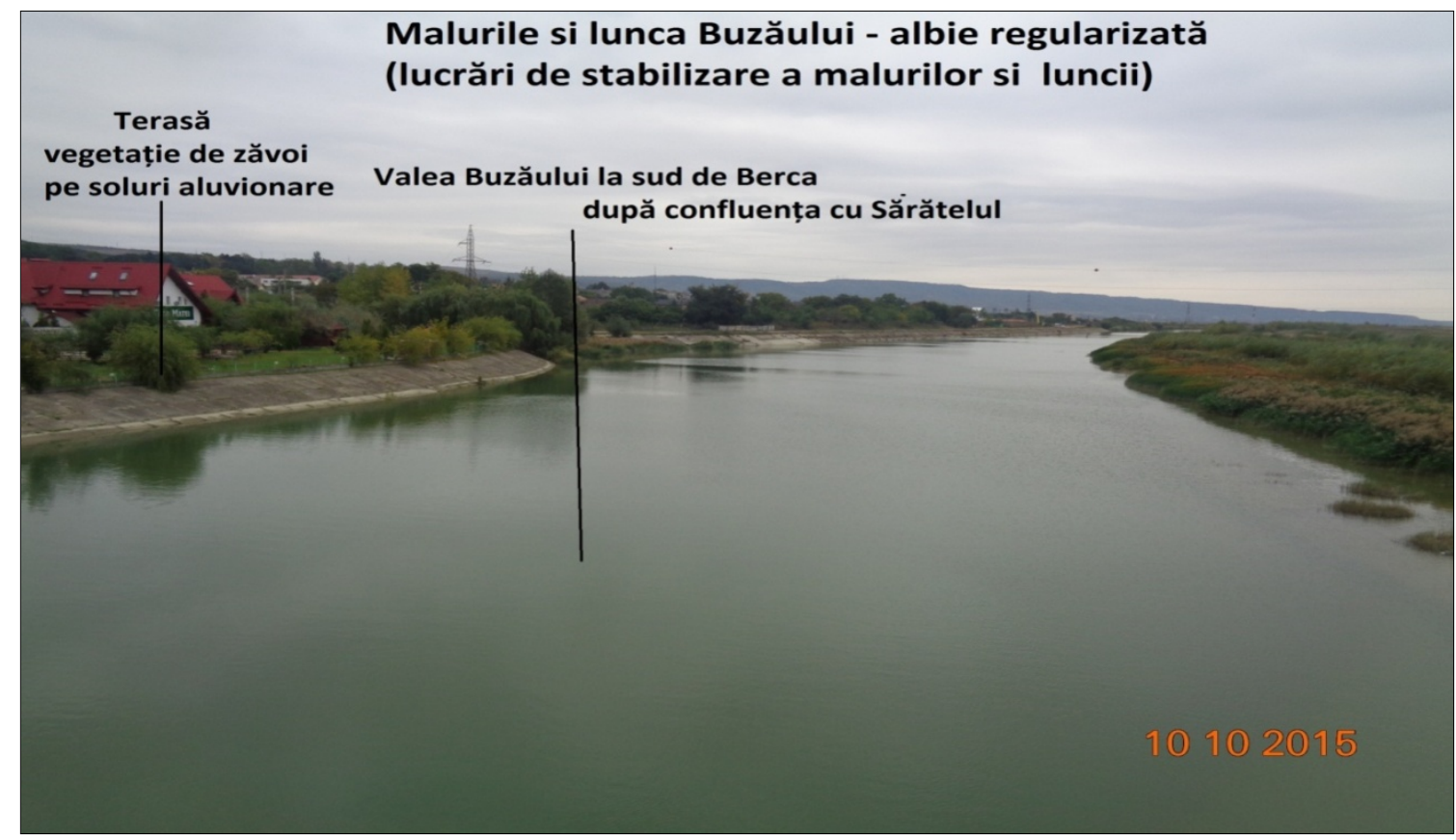

Figure 4. Works to stabilize the banks and floodplain Buzau (photo: Constantin Moraru, 2015)

The floods caused by the river overflows Buzau have affected many houses and objectives of the socioeconomic development, but and objectives of the infrastructure (roads, bridges ). The qualities of the new work with the role of defense against flood on the river Buzau could not be tested in the flood.

In addition, the wife in the course of or east, has been the main risk to the flood they appearing rather as a result of the aggressive erosion of the banks, leading to material damage important and put in danger the population spread on almost the entire length of the Buzău, except in the area of the keys.

This situation explains the impossibility of creearii s of accumulations, because there are few areas without infrastructure and villages are subject to exposure to spills and premises for the change of place being detailing.

Measures relating to the management of floods in the catchment area of the Buzau presented are:

- prevention of major damage to the future floods along the river Buzau;

- considerable reduction in the economic and social consequences of floods in the basin, through a combination of structural measures (local jetties) and measures nestructurale, selected according to the conditions and local targetsc;

- complete change in the management of the water courses, the protection of the environment, the conservation or restoring biodiversity and biological corridors in flood majeure, avoid destruction of interesting habitats along the river and the provision of space of the river for the evolution of the natural morphological characteristics.

All these aspects set out lead to the conclusion that it is necessary to amend the full management of the course the river Buzau and not only (Gastescu,P., Neagu, I.,1986).

\section{BIBLIOGRAPHY}

[1] Balteanu, D., (1974), Relations between the drips mud and heavy erosion in modeling side the Subcarpathic Buzau. Studies and research of Geologie, charts and Geography. XXI Series, Bucharest

[2] Gâștescu, P., Neagu, I., (1986), Buzau county's water resources, geographic environmental research in Buzau county, Romanian Academy, Institute of Geography, Bucharest.

[3] Posea, G., (1971), Evolution Buzau valley. Geography Buzau county and environs. Bucharest.

[4] Posea,G., Ielenicz, M., (1971), The Geography Buzaului and of the surroundings , Academy publishing house, Bucharest 
"Mircea cel Batran" Naval Academy Scientific Bulletin, Volume XIX - 2016 - Issue 2 The journal is indexed in: PROQUEST / DOAJ / Crossref / EBSCOhost / INDEX COPERNICUS / DRJI / OAJI / JOURNAL INDEX I I2OR / SCIENCE LIBRARY INDEX / Google Scholar / Academic Keys/ ROAD Open Access I Academic Resources / Scientific Indexing Services / SCIPIO / JIFACTOR

[5] Popp, N. (1975), Balance and imbalance in the geographical landscape of Romanian the Subcarpathic. Scientific paper Pedagogical Institute Oradea.

[6] Ujvari, I. (1972), Romanian water geography, Scientific publishing, Bucharest.

[7] Zavoianu, I. (1986), Spill solid and land degradation in the Subcarpathic Buzau in Buzau county geographic research. Bucharest. 